\title{
The Emerging International Taxation Problems
}

\author{
James G. S. Yang ${ }^{1, *}$ and Victor N. A. Metallo ${ }^{1,2}$ \\ 1 Department of Accounting \& Finance Montclair, Montclair State University, Montclair, NJ 07043, USA; \\ metallov@montclair.edu \\ 2 Stillman School of Business, Seton Hall University, South Orange, NJ 07079, USA \\ * Correspondence: yangg@montclair.edu, Tel.: +1-973-783-4713
}

Received: 27 October 2017; Accepted: 19 December 2017; Published: 2 January 2018

\begin{abstract}
The problems of tax evasion and tax avoidance are as old as taxes themselves. Between 2015 and 2016 alone, many U.S. multinational corporations were involved in tax disputes with the European Commission. From a historical perspective, these disputes are unprecedented as they have resulted in tremendous amount of tax penalties. The most notable case was Apple for $€ 13$ billion of unpaid tax. This article discusses what tax strategies these corporations used that caused such disputes. It specifically investigates seven corporations: Apple Inc., McDonald's, Starbucks, Fiat, Amazon, Google, and Ikea, and elaborates on the following tax strategies: high royalties, intercompany transfer pricing, intercompany loans, and source of income in a high-tech industry. This article also discusses the European Commission's charges of tax evasion and how these corporations defend against them. When multinational corporations are operating abroad, they must observe not only domestic tax law but also international law.
\end{abstract}

Keywords: international taxation; the European Commission; worldwide tax system; territorial tax system; domestic-sourced income; foreign-sourced income

JEL Classification: M48

\section{Introduction}

In the past 10 years, many U.S. multinational corporations moved their tax domiciles to Europe. The purpose was to take advantage of the differences in tax laws between the United States (U.S.) and European countries. Many of these corporations found themselves in conflict with the European Commission (the Commission), which imposed hefty penalties on them. Who are involved? How much were the penalties? What are the disputes? How did these corporations defend themselves? The answers to these questions are discussed below. They include a discussions of various corporations' tax strategies and what led to the conflict.

This paper specifically investigates seven corporations. They are Apple, Inc. concerning income shifting from the U.S. to Ireland; McDonald's involving the use of controlled foreign corporations; Starbucks using intercompany transfer pricing; Fiat extending intercompany loan to its subsidiaries; Amazon transferring profits among subsidiaries; Google claiming U.S. income source of high-tech product; and Ikea charging high royalties to its subsidiaries. From these actual cases, this paper points out that the multinational corporations' tax strategies are actually designed for tax avoidance or evasion.

\section{Literature Review}

It is well known that international tax law has many loopholes, and in the past three decades, multinational corporations (MNC) have exploited them. On 30 August 2016 the European Commission sent shockwaves throughout the entire investment community when it imposed a massive \$14.5 
billion in penalties on Apple, Inc., USA, for receiving illegal tax subsidies from the Irish government. Further, on 24 December 2016, the Organization of Economic and Cooperation Development (OECD) announced a universal agreement to address these issues. The tax loophole misuses have become too serious to neglect anymore. This section reviews some of the literature to see what has been done and what lies ahead.

Morgan (2016) investigated the root of international taxation problems, arguing profits ought to be reported as to the place where they are created. Presently, MNCs derive profits from many places around the world, which can confuse the origin of their profits. The current law cannot keep pace with the current business environment, as it leads to abuses. Morgan states, " ... The underlying issues are rooted in the capacity of a multinational corporation to construct organizational circuits that shift where sales, revenue and profit are reported. The capacity in turn becomes a focus because of the way MNC are treated as a series of separate entities, subject to the arm's length principle ...." This means contemporary international tax problems arise from the obsolescence of current law. Thus, reform is required.

Arel-Bundock (2017) indicated international tax treaties among countries give rise to treaty shopping. This is where the problem of tax loopholes begins. Arel-Bundock claims, "The international tax system is a complex regime composed of thousands of bilateral tax treaties. These agreements coordinate policies between countries to avoid double taxation and encourage international investment ...." This implies that multilateral tax treaties cause double taxation. In order to alleviate the ill-effect, the solution is more treaties. As a result, it provides the MNC with an opportunity for treaty shopping.

Olbert and Spengel (2017) demonstrated that current international law has been out of touch with what is done in practice and in fact is not up to speed with advances in technology. They state, "The phenomenon of digitalization is considered the most important development of the economy since the industrial revolution and one of the major drivers of growth and innovation. At the same time, the digital economy is associated with major challenges for the international tax system. Traditional tax laws are governing new ways of conducting business, but current international tax law and its underlying principles may not have kept pace with changes in global business practices." As a result, international tax law as it stands is inadequate and does not address current business practices, which tends toward abuse.

Transfer pricing is probably the most serious problem in international taxation. Riley (2014) pointed out that:

It is a general maxim that taxpayers want to minimize their tax liability to the greatest extent possible. However, taxpayers who overzealously pursue this aim risk crossing the line separating permissible tax avoidance from impermissible tax evasion. In the realm of international business tax law, nowhere is this issue more pressing than in the arena of transfer pricing, in cases where the taxpayer is a multi-national enterprise (MNE) comprised of corporate entities located in several tax jurisdictions worldwide ....

This means that the multinational enterprises increasingly abuse 'transfer pricing' between the parent company and its controlled foreign corporation as a vehicle to shift its profit from a lower-tax country to a higher one. The only purpose is to minimize its overall tax liability.

There are many more examples like the above, however, these three articles all uniformly and unequivocally point to where the international tax dilemma lies. Current businesses are globalized. Modern business operations are digitized, and the stakeholders of a MNC are expanded. As a consequence, the old system can no longer adapt to the future. This inevitably creates inconsistencies and contradictions, leading to MNCs' exploitation of loopholes. Governments, therefore, need to take action to update the current system.

The next section investigates what the tax loopholes are and how MNC manipulate their tax strategies to circumvent the law. There is further analysis surrounding governmental solutions to prevent abuses. 


\section{U.S. Corporations vs. the European Commission}

In the past few years, the European Commission ordered nine multinational corporations to repay a heavy amount of back taxes to many European governments for receiving illegal tax subsidies. These corporations are as follows: Apple, $€ 13$ billion to Ireland in 2016 (The European Commission 2016); McDonald's, $€ 1$ billion to Luxembourg in 2015; Amazon, $€ 400$ million to Luxembourg in 2016; Starbucks, $€ 30$ million to Netherlands in 2015; Google, £130 million to the UK in 2016; Gap, £130 million to the UK in 2016; Microsoft, $€ 497$ million to various European governments in 2004; Ikea, $€ 1$ billion to Netherlands in 2015; and Fiat, $€ 30$ million to Luxembourg in 2015.

The penalties are extremely heavy and the range of corporations' businesses is expansive. Industries include, but are not limited to, technology, online sellers, fast-food chains, retailers, and auto makers. This indicates that tax disputes must be quite serious. In fact, the most tumultuous disputes are with Apple and Google, because both belong to a new frontier of industrial development-computer technology. A new principle of taxation perhaps may need to be created to deal with this phenomenon.

The disputes between these multinational corporations and the Commission concern many aspects, such as the question concerning the source of income, royalties, transfer pricing, and intercompany loans. They are the vehicles employed by these corporations to carry out their tax-planning strategies. In the next section, the details are analyzed.

\section{Apple}

Apple, Inc. (Cupertino, CA, USA) expanded operations to Ireland in 1980. In the infancy of this expansion, Apple established a subsidiary of Apple Operations International (AOI) in Ireland, which in turn owned four subsidiaries: Apple Sales International (ASI) in Ireland, Apple Operations Europe, Apple Singapore, and Apple Asia. ASI operates eight retail chain stores in Belgium, France, Germany, Italy, Netherlands, Spain, Switzerland, and UK. ASI outsourced the production of iPhone to China and distributed the product to all its subsidiaries for sales.

\subsection{Apple as A Foreign Corporation in Ireland}

Apple relocated its computer business to Ireland for the purpose of taking advantage of the lower tax rate: the U.S. tax rate is $35 \%$, while its Irish counterpart is as low as $12.5 \%$.

Apple negotiated with the Irish government that AOI be treated as a "foreign corporation", under which its foreign source income is tax-free in Ireland. Because Apple expanded into Ireland, all foreign income is non-taxable in Ireland. In other words, AOI's income earned from sales in the U.S. and the rest of Europe is tax-free in Ireland. The tax savings can be very substantial applying this rule along with the lower tax rate.

In order to avail itself of this tax advantage, in 1991, Apple convinced the Irish government that its income is a foreign source income because Apple is managed and controlled by its headquarters in the U.S. The Irish government agreed, despite the loss in revenue, because it desired to attract Apple's investment capital. This tax incentive was desirable as a benefit to Ireland, but eventually the decision would lead to litigation.

\subsection{Apple's U.S.-Sourced Income}

The other side of the issue concerns that if Apple's income in Ireland is considered foreign income, what are the consequences of the U.S. tax? If income is earned in the U.S., then it is subject to U.S. tax.

Apple argued that the iPhone and its other computer products were exclusively invented and developed in the U.S. The income from sales is based in the U.S., and as such, it should be treated as a U.S.-sourced income subject to U.S. tax. To reiterate, the U.S. tax rate for corporate income is as high as $35 \%$, whereas, in Ireland it is $12.5 \%$ (Pomerleau 2014). However, Apple does not pay income tax in the U.S. anyway. 
When a transaction involves two different countries, the source of the income will determine which country has jurisdiction.

For example, General Motors (GM) sells a car to a customer in Ireland. The Irish government can impose a tax on the sale because the source of the sale is an Irish customer. However, Apple argues its sales of iPhones to customers in Ireland are not taxable by the Irish government, because the iPhone was invented in the U.S. and most of the profit is tied to the technology, which continues to be developed in the U.S. Hence, according to Apple, the sale is U.S.-sourced income.

\subsection{Apple's Allocation of Profits Among Subsidiaries in Europe}

In the beginning, when Apple negotiated with the Irish government for non-taxable status for AOI, it intended all profits allocated to AOI would be tax-free. ASI operates eight retail chain stores in various European countries plus other subsidiaries in Singapore and Asia. All of their transactions were structured in such a way that ASI is the only seller of Apple products. All profits belong to ASI in Ireland and not in other countries. ASI then allocated the greater portion of its profits to AOI. As a benefit, AOI paid no tax and ASI paid only a meager amount of tax to the Irish government.

This strategy eventually reduced Apple's effective tax rate in Ireland from the regular rate of $12.5 \%$ to as low as $1 \%$ in 2003 , to $0.05 \%$ in 2011 , and to $0.005 \%$ in 2014 . In 2011 alone, ASI earned $€ 16$ billion in profits but paid only $€ 10$ million in tax. In 2007 , the Irish government agreed to this profit allocation scheme though it was cancelled in 2015.

\subsection{Apple's U.S. Tax Liability}

Apple contends that its profits in Ireland must be treated as U.S. sourced income, and therefore, not taxable in Ireland. At the same time, Apple argues it does not owe the U.S. government any tax even though it claims sales are U.S. sourced. It can do this because there is a loophole in U.S. tax law. When a U.S. multinational corporation earns profits from a foreign country, only the cash dividends received is subject to taxation in the U.S. (IRC $\$ 871$ (b)). If no cash dividends are received, then no tax payment is due. Apple in Ireland never paid any dividends to Apple headquarters in the U.S., therefore, it claims it does not have to pay U.S. taxes.

The general rule is tax must be paid either in a company's own home country or in the host country. Yet, under the above scenario, Apple pays no tax to either the Irish government or the U.S. government. This dilemma reveals the contradiction in the international taxation system and the territorial income tax system in Ireland and how Apple takes full advantage of it.

\subsection{The Commission's Charges}

The Irish government granted AOI status as a foreign corporation. In fact, AOI is duly registered in Ireland as an Irish corporation. The reason to do this is to treat Apple's income in Ireland as foreign-sourced income. Thus, Apple's income in Ireland is tax-free. If fact, Apple's income in Ireland is deemed earned in Ireland. This, however, violates a fundamental principle of international taxation law where tax is normally paid in a country where the product is sold.

Even though Apple's tax status in Ireland is that of a foreign corporation, Apple also treated the income in Ireland as U.S.-sourced income. Tax is due in the U.S. only for the cash dividends received, but AOI never paid out any cash dividends. The purpose is to avoid taxation in the U.S. As a result, Apple did not pay any tax to any country, and therefore, this tax accounting is arguably unjustified.

Apple's profit allocation scheme among European countries seems unfair. All profits go to AOI and none belong to its other subsidiaries. In fact, AOI has no sales or operations, making it an entity on paper that serves as a tax haven. AOI deserves no profits at all. Instead, profits should be attributed to the countries where the Apple products were sold. Apple's profit allocation scheme is inconsistent with the principle of an 'arm's-length transaction', where parties are on equal footing. In addition, its accounting distorts the measurement of performance among all of Apple's subsidiaries. 
It appears the purpose of its strategy is to increase the taxable income for AOI and decrease taxable income for other subsidiaries, but AOI is a tax-free entity. As a result, the effective tax rate is so low that it constitutes illegal tax subsidies from the Irish government to Apple. Other corporations in Ireland cannot get away with this. Further, it jeopardizes competition, which is prohibited by the European Union State Aid rules.

The Commission challenged Apple's actions. As a consequence, on 30 August 2016, the Commission ordered Apple to repay $€ 13$ billion in back taxes to the Irish government for the illegal tax subsidies received in the past 10 years (The European Commission 2016).

\subsection{Apple's Defense}

With respect to the charge of illegal tax subsidies, Apple argued it entered into agreements with the Irish government in 1991 and 2007. Both sides agreed to the tax status of AOI and the profit allocation scheme. At that time, the Irish government desperately needed investment capital from Apple for its developing economy. There is nothing wrong with a government providing tax incentives to a foreign corporation. Incentives are also available to other corporations as well. Apple was in a position to take advantage of this opportunity, and it is absolutely legal. Apple paid all taxes under the Irish law. Apple did not violate any Irish law. Therefore, Apple rejected the charge of receiving illegal tax subsidies.

In reference to the claim that Irish income is U.S.-sourced income, Apple alluded, in the old days, income was earned in the place where the product was sold. Presently, in the new high-tech environment, income is earned in the place where the technology is invented, not where the product is sold. High-technology requires a tremendous amount of capital and efforts to develop it. Sales activity accounts for only a meager part of the profits earned. As a result, Apple contends, since the iPhone was invented in the U.S. and not in Ireland, attributing iPhone profits to the U.S. territory is justified (Cook 2016). Therefore, Apple also rejects the charge that this is a violation of basic principles of international taxation.

In terms of the charge with failure to pay taxes in the U.S., Apple contended that AOI was granted status as a foreign corporation, and thus its foreign source income is tax-free. This is equivalent to the traditional territorial tax system. There is a discrepancy between the worldwide income tax system in the U.S. and the territorial income tax system used in Ireland. The latter permits Apple's income in Ireland not to be taxed. The former permits Apple's income from Ireland not to be taxed until the cash dividends are received. If no cash dividends are ever received from Ireland, then no tax payment is due in the U.S. AOI did not intentionally pay any cash dividends back to the U.S. As a result, Apple never paid tax to the U.S. government. This is a tax loophole between these two systems. Apple took advantage of it, and it is legal. Therefore, Apple further rejected the accusation that it somehow evaded to pay tax in the U.S.

The Commission's order to the Irish government and Apple is akin to it acting like a super government existing above all other governments. Apple signed a contract with the Irish government, but not with the Commission. The penalties imposed applied 10 years retroactively. The imposition of the order can create confusion and uncertainty for all private corporations that operate in Europe. The legal basis of the Commission's action appears to be questionable.

The dispute boils down to one issue. Can the Irish government give tax subsidies to Apple? The granting of tax subsidies was a common practice in many developing countries. A typical example is China in the early 1990s granting tax relief for foreign joint ventures. This is something that is commonplace.

The Commission's ruling has been appealed to the European Court of Justice. It is still pending.

\section{McDonald's}

In Luxembourg, McDonald's established McDonald's Holding Company, which in turn set up McDonald's Franchising Company to operate the restaurant chain. McDonald's Franchising operates 
numerous restaurants in Europe and Russia. These restaurants are required to pay very high royalties to McDonald's Franchising for using its trade name, products, and services. McDonald's Franchising also established two branches: one in Switzerland and the other in the U.S. The U.S. branch is a subsidiary of McDonald's Franchising.

The Luxembourg government agreed to treat McDonald's Franchising as a foreign corporation; hence, its foreign-sourced income is tax-free in Luxembourg. When McDonald's Franchising receives royalties from all restaurants, the whole amount is paid to the Swiss branch. The Swiss branch then transfers the amount to the U.S. branch.

As a result of these transfers, the entire amount of royalties goes to U.S. branch in the U.S. No profit is left in Europe. The U.S. branch is structured so that it is a subsidiary of McDonald's Franchising. As long as McDonald's Franchising derives at least 25\% of its operation from Europe, the U.S. branch's income is not taxable in the U.S. This is because McDonald's Franchising is not a U.S. corporation, according to IRC $\$ 871$ (b). In fact, all of McDonald's Franchising's income is derived from Luxembourg. Therefore, the amount of royalties received by the U.S. branch is nontaxable in the U.S. As a result, McDonald's pays no tax at all to any country.

The Commission charged that the royalties paid from all restaurants to McDonald's Franchising are far too high as compared to other comparable restaurant chains. McDonald's is using high royalties as a vehicle to shift income from a high-tax country to a lower one. It is equivalent to illegal tax subsidies being given by the Luxembourg government to McDonald's. The tax dispute is centered on the fair amount of royalties. On 3 December 2015, the Commission ordered McDonald's to repay $€ 1$ billion to the Luxembourg government (The European Commission 2015a). The case now is before the European Court of Justice.

\section{Starbucks}

The Starbucks Corporation set up Starbucks Manufacturing Company in Netherlands. It makes and sells roasted coffee beans and related products to Europe, the Middle East, and Africa. Starbucks also created Switzerland Starbucks Trading Company in Switzerland, which purchases coffee beans from other countries and sells the beans to Starbucks Manufacturing at an inflated price. The group further set up Alki Company in the UK specializing in coffee development activities. It charged Starbucks Manufacturing very high royalties.

As a result of the above strategies, the profit of Starbucks Manufacturing in Netherlands is reduced to a very low amount. The purpose is to avoid tax liability in Netherlands. The Commission claimed the price of the green coffee beans purchased from Switzerland Trading is too high priced, as compared to the current market price. It does not represent a fair price in an 'arm's-length transaction'. Starbucks Manufacturing is using 'intercompany transfer pricing' as a tool to shift income from Netherlands to Switzerland. The transfer pricing technique was a traditional technique employed by MNCs to shift income from a high-tax country to lower tax one. The purpose is to reduce the tax liability. The transfer pricing is supposed to represent the incremental value of the merchandise that is transferred. However, it has been highly abused as a tool for income manipulation.

Further, the royalties charged by Alki are also out of proportion as compared to a similar coffee development concern. As a consequence, Starbucks Manufacturing did not pay a fair share of tax to Netherlands government. The under-paid tax is as much as $€ 30$ million since 2008. On 21 October 2015, the Commission ordered Starbucks to repay the back tax to Netherlands government. The case is pending before the European Court of Justice.

\section{Fiat}

Fiat Corporation set up many branches in Europe to sell its automobiles. In order to finance the branches, it established Fiat Finance and Trade Company in Luxembourg which gives loans to all branches. The interest on the loan is based on the amount of capital base and the interest rate. The interest income received by Fiat Finance and Trade becomes taxable in Luxembourg. However, 
the tax rate in Luxembourg is as high as $29.22 \%$. In order to reduce its tax liability, Fiat Finance and Trade intentionally reduced the capital base and interest rate to an unreasonably low level. However, as an incentive, the Luxembourg government agreed to it for the purpose of attracting Fiat's business.

This agreement caught the Commission's attention. It complained that the tax incentive program is not available to other companies in Luxembourg, and thus discriminates against other companies. It creates unfair competition among all companies because it favors Fiat alone. It is illegal under European State Aid rules. Fiat is using intercompany loans to shift income from Luxembourg to other lower-tax countries in Europe. Thus, the tax dispute centers on the question of fairness of the intercompany loan interest.

The amount of under-paid tax amounts to $€ 30$ million since 2012 (The European Commission 2015b). On 21 October 2015, the Commission ordered Fiat to repay such an amount back to the Luxembourg government. The case has been appealed to the European Court of Justice.

\section{Amazon}

Today, just about every consumer product can be purchased online via the Internet, ranging from a computer to a shirt. The phenomenon of buying merchandise over the Internet is growing, because it can accommodate a greater variety of choices. Further, the merchandise can be delivered to the buyer from different locations. If the delivery location involves two different countries, there can be different tax rates. Amazon is so large that it can decide where best to deliver the merchandise, and thus take advantage of a lower tax rate.

For example, a customer in the U.S. places an order to buy a shirt on Amazon. Should Amazon deliver this shirt from its branch in the U.S. or the one in Ireland? It should be noted that the income tax is imposed in the country where the merchandise is sold. The tax rate is as high as 35\% in the U.S. and as low as $12.5 \%$ in Ireland. Obviously, it is more profitable to deliver the shirt from Ireland rather than from the U.S. and Amazon can benefit from this tax loophole.

Amazon based its headquarters for their European operations in Luxembourg. It then negotiated with the Luxembourg government to treat the entity as a foreign corporation. Amazon's income is tax-free in Luxembourg. In turn, it structures all sales in all other European countries as sales from the Amazon headquarters in Luxembourg. As a result, the amount of profits in all European countries are treated as 'Luxembourg-sourced income'. However, Amazon is not required to pay income tax in Luxembourg.

The Commission disagrees with Luxembourg's tax policy in granting a tax-free status to Amazon. It is tantamount to illegal tax subsidies. The unpaid tax is $€ 400$ million since 2003 (Chee 2016). In May 2016, the Commission ordered Amazon to repay it to the Luxembourg government. Amazon appealed to the European Court of Justice. It is still pending.

\section{Google}

Today, any merchandise or service can be searched for online. Google offers such a service. It has no stores anywhere in the world; whereas, its website appears everywhere. Almost anyone can go to its website to search for anything, including this article. Since it sells no merchandise, where does Google earn its income? It comes from advertising fees.

Since the advertisers are scattered everywhere around the world, the question becomes where to attribute the source of income. It depends on where the advertiser is located. If the advertiser is located in a foreign country, it is foreign-sourced income and it would be taxed in that country. If the income is U.S.-sourced income, it is taxed in the U.S. For example, an advertiser in the U.K. pays advertising fees to Google. The question then is should the income be taxed in the U.K. or in the U.S.

Google contended that the income from the online searching service is derived from where the search engine technology is invented, not from where service is rendered. Google's searching technology was solely developed in the U.S. Therefore, its searching service income should justifiably 
be treated as U.S.-sourced income. Using the same logic, Apple's income also should not be taxed in the U.K. but in the U.S.

The Commission rejected Google's argument. In the past, Google always treated the U.K.'s income as a U.S.-sourced income. Hence, no tax was paid to the U.K. government. The unpaid tax amounts to $€ 130$ million for the period of 2005-2015 (Bowers 2016). In January 2016, Google agreed to pay this amount of back tax to the U.K. Again, this tax dispute involves the question as to where the income is sourced, just as in the case of Amazon. This case has been settled.

\section{Ikea}

Ikea is a famous furniture manufacturing company with headquarters in Sweden. It has many branches in European countries. With regard to the Netherlands branch, it requested that the Netherlands government treat it as a foreign corporation. As such, income from other countries would be tax-free under the territorial income tax system. Ikea also requires all other branches to pay royalties to Netherlands branch. The royalties are so high that all profits are converged in the Netherlands branch. As a result, it incurs no tax liability anywhere. In substance, Netherlands is considered to be a tax haven.

Ikea then sent funds from Netherlands to another tiny tax haven country, Liechtenstein, which is located between Switzerland and Austria. Liechtenstein imposes no income tax. Again, Ikea ends up with no tax liabilities in any country.

The Commission claimed the royalties are unreasonably high. The Netherlands government's special tax treatment for Ikea is equivalent to illegal tax subsidies. The under-paid tax amounts to $€ 1$ billion in 2009-2014 (Bowers 2016). The Commission ordered Ikea to pay it back to the Netherlands government. The case is appealed in the European Court of Justice.

There are many more examples of multinational corporations employing similar strategies, such as Gap and Microsoft, that the Commission has been investigating.

\section{High-Tech as Source of Income}

The tax dispute between Apple and the Commission begs the question as to whether a new tax rule should be employed that bases income on whether it is derived from where the product is developed or sold. In the high-tech environment of today, the source of income is determined at the place where its technology is developed and not in the country where the product is sold.

In the early 2000s, Internet commerce began its development stage. The most controversial case during that period involved the so-called "Amazon Tax" (The Supreme Court of the State of New York 2008). At that time, Amazon was located in Seattle, Washington. It had no branches in New York, but it sold its merchandise to customers in New York. This created an issue for Amazon as to whether it was required to collect sales tax from the buyers in New York. Amazon argued that it has no branch or 'physical presence' in New York, and thus it is not required to do so. The New York State government claimed that the profit is derived from New York, and hence Amazon was required to pay it. The issue then turns on whether 'physical presence' in New York is necessary to collect the tax, or whether the sale in New York creates an 'economic nexus' sufficient to impose the tax.

Perhaps the economic nexus theory of tax jurisdiction should be applied in international tax law. In Apple's case, the Commission contended that the iPhone was sold in Ireland, and therefore, its income should be taxed in Ireland. Apple, however, argued that iPhone profits are earned in California-the place where they were invented-thus, it does not owe any tax to Ireland. If the economic nexus theory were applied, the sale in Ireland would be taxable in the U.S., since the sale of the iPhone created an economic nexus with Apple in the U.S.

\section{Emerging Problem in International Taxation}

This paper investigates tax strategies of seven multinational corporations and points out why they have caused so much furor. A multinational corporation invariably derives income not only from 
domestic sources but also foreign sources. The imposition of two taxing systems, namely the worldwide income tax system and the territorial income tax system, is problematic because a company can always shift income from one country to another so that it will always be considered foreign-sourced income. The income from a host country becomes tax-free in a home country.

For example, Apple can set up a subsidiary corporation in Ireland and then shift its sales revenue from the UK to Ireland. The UK would have no profit and the income in Ireland would be considered tax-free because it is foreign-source income. As a result, Apple paid no tax to either the UK or Ireland. Apple exploited a serious deficiency in the territorial income tax system.

There are many vehicles a multinational corporation can utilize to shift income from one country to the other. The most popular one is charging high royalties-a strategy that companies, such as Amazon, McDonald's, Ikea, and Gap, employ. As discussed above, another popular device is high intercompany transfer pricing used by Starbucks. Fiat uses intercompany loans, and others, such as Google, use the origin of income of high-tech product. The legality of these structures is still not settled, as the Commission continues to challenge them.

In order to attract investment capital, many European governments grant multinational companies special tax status as a foreign corporation. As such, their foreign-sourced income is tax-free. The former may be legal, but the latter appears to be a violation of the international taxation rules.

\section{Conclusions}

In the past 10 years, many U.S. multinational corporations relocated their businesses to Europe for the purpose of taking advantage of lower tax as compared to their U.S. counterparts. However, in order to achieve this objective, it requires sophisticated tax strategies. As a result, these companies were involved in tax disputes with the European Commission, resulting in massive tax penalties. This paper discusses their tax strategies and, more importantly, points out their consequences.

This paper specifically investigates seven corporations. Ireland has the lowest tax rate in the world. Apple, Inc. established a subsidiary corporation in Ireland and uses it as a conduit to transfer all profits from European subsidiaries to Ireland. The purpose is to reduce Apple's tax liability.

McDonald's moved to Luxembourg and operates many restaurants in Europe but charges them very high royalties. All profits are now funneled to Luxembourg, but they are tax-free.

Starbucks set up its coffee bean roasting business in Netherlands. Starbucks also operated many restaurants in Europe and charged them an inflated price for roasted coffee beans. As a result, Starbucks, using the transfer pricing technique, shifted all profits to the Netherlands tax free.

Fiat set up a financing and trade company in Luxembourg that in turn extended loans to other branches in Europe, but it intentionally charged very low interest. The purpose was to disburse its profits from Luxembourg to other countries. Fiat, therefore, uses intercompany loans as a device to shift income.

Amazon also established its headquarters in Luxembourg. It then structured all its sales in other European countries as sales from Luxembourg. As a result, the profits are tax-free.

Google sells high-tech services in every country in the world. They claim that its high-tech is invented in the U.S., and hence it is U.S. sourced income which is not taxable in other countries. However, Google never distributed dividends back to the U.S. As a result, Apple's foreign source income is all tax-free.

Ikea established its headquarters in the Netherlands for all its European branches. However, the headquarters charged high royalties against all branches. All profits now go to the Netherlands with no consequence because it is a tax-free entity.

In light of the above, all these MNCs seem to have one strategy in common: they all asked their host countries for the tax status of a foreign corporation by which they then become a tax-free entity.

They employ transfer pricing to shift profit from a high-tax country to a low-tax country, with the purpose to minimize their tax liability. 
Author Contributions: James G. S. Yang conceived and wrote the paper; Victor N. A. Metallo performed research and edited the paper.

Conflicts of Interest: The authors declare no conflict of interest.

\section{References and Notes}

Arel-Bundock, Vincent. 2017. The Unintended Consequences of Bilateralism: Treaty Shopping and International Tax Policy. International Organization 71: 349-71. [CrossRef]

Bowers, Simon. 2016. Google's Tax Deal with the UK: Key Questions Answered. The Guardian, January 29. Available online: https:/ / www.theguardian.com/technology/2016/jan/29/googles-tax-deal-with-the-ukkey-questions-answered-chancellor-taxes (accessed on 27 December 2016).

Chee, Foo Yun. 2016. Exclusive: EU Aims to Rule on Amazon's Luxembourg Tax Deal. Reuters, Business News, May 19. Available online: http:/ / www.reuters.com/article/us-eu-amazon-com-taxavoidance-exclusiveidUSKCNOYA2Q4 (accessed on 20 December 2017).

Cook, Tim. 2016. A Message to the Apple Community in Europe, Apple Website, August 30. Available online: http:/ / www.apple.com/ie/customer-letter/ (accessed on 5 January 2017).

IRC $\S 871(b)$.

Morgan, Jamie. 2016. Corporation Tax as a Problem of MNC as Organizational Circuits: The Case for Unitary Taxation. The British Journal of Politics and International Relations 18: 463-81. [CrossRef]

Olbert, Marcel, and Christoph Spengel. 2017. International Taxation in the Digital Economy: Challenge Accepted? World Tax Journal 9: 3-46. Available online: https://www.ibfd.org/sites/ibfd.org/files/content/img/ product/april_ppv_wtj_2017_01_int_4_international_taxation.pdf (accessed on 13 November 2017).

Pomerleau, Kyle. 2014. Corporate Income Tax Rates around the World. Tax Foundation, August 20.

Riley, Mary. 2014. Transfer Pricing and International Taxation: A Continuing Problem for Taxing Authorities. Irvine: LexisNexis Tax Law Community, November 17.

The European Commission. 2015a. The European Commission Press Release, "State Aid: The Commission Open Formal Investigation INTO Luxembourg's Tax Treatment of McDonald's". Brussels, December 3. Available online: http:/ / europa.eu/rapid/press-release_IP-15-6221_en.htm (accessed on 27 December 2016).

The European Commission. 2015b. The European Commission-Press Release, “The Commission Decides Selective Tax Advantages for Fiat in Luxembourg and Starbucks in the Netherlands Are Illegal under EU State Aid Rules". Brussels, October 21. Available online: http:/ / europa.eu/rapid/press-release_IP-15-5880_ en.htm (accessed on 27 December 2016).

The European Commission. 2016. Press release, "State Aid: Ireland Gave Illegal Tax Benefits to Apple Worth up to $€ 13$ billion". Brussels, August 30. Available online: http:/ / europa.eu/rapid/press-release_IP-16-2923_en. htm (accessed on 5 January 2017).

The Supreme Court of the State of New York. 2008. Amazon.com, LLC, v. New York State Department of Taxation and Finance. County of New York. Identification No. 601247/08. The Supreme Court of the United States (1941), Nelson (Iowa) v. Sears Roebuck \& Co. 312 U.S. 359 (1941).

(C) 2018 by the authors. Licensee MDPI, Basel, Switzerland. This article is an open access article distributed under the terms and conditions of the Creative Commons Attribution (CC BY) license (http:/ / creativecommons.org/licenses/by/4.0/). 